\title{
Establishment of post-harvest early-developmental categories for viability maintenance of Araucaria angustifolia seeds
}

\author{
Cristhyane Garcia Araldi ${ }^{1}$ and Cileide Maria Medeiros Coelho ${ }^{2^{*}}$
}

Received: March 18, 2015. Accepted: August 6, 2015

\begin{abstract}
Araucaria angustifolia seeds are recalcitrant, and their metabolism remains high during storage. This research aimed to describe the initiation of germination in A. angustifolia seeds during storage in order to standardize the assessment of physiological quality and to promote seed conservation. Seeds were collected from two populations and stored for 270 days in the natural laboratory environment and cold chamber. Seeds were classified according to four early developmental stages: I - mature seeds; II - seeds with elongation along the embryonic axis; III - beginning of root protrusion; IV - advanced germination stage, with seedling shoots. After categorization, physical and physiological quality was assessed. In freshly collected seeds, only category I was observed. At 270 days, approximately $40 \%$ of seeds were in category III in laboratory conditions, while the maintenance in a cold chamber delayed germinative metabolism. Viability tests showed that seeds in categories III and IV were more susceptible to damage caused by storage. In conclusion, the percentage of viable A. angustifolia seeds depends on the development stage after collection. Seeds that have reached early developmental category III should be prioritized for propagation, while those remaining in categories I and II should be longer stored with periodic assessment for reduction in physiological quality.
\end{abstract}

Keywords: Brazilian pine, longevity, recalcitrant seeds, seed conservation, seed development

\section{Introduction}

Araucaria angustifolia (Brazilian pine) is a key species of the Brazilian Atlantic Rain Forest (Veloso et al. 1991; Coutinho \& Dillenburg 2010), being its only native gymnosperm of economic importance (Silveira et al. 2008; Elbl et al. 2014). Its seeds are consumed by humans and are the most important food source for several wild mammals and birds during the winter (Stefenon et al. 2009; Reis et al. 2014). The seeds are recalcitrant, with a short conservation period under natural conditions, with at least a $60 \%$ viability reduction at 4 months post-harvest (Fowler et al. 1998; Amarante et al. 2007; Garcia et al. 2014). Given the need for the conservation of genetic resources, it is important to note that $A$. angustifolia has been classified as critically endangered by IUCN (2013).

Studies on the metabolism of recalcitrant seeds have been performed by several authors (Barbedo \& Bilia 1998; Song et al. 2003; Berjak \& Pammenter 2008; Caccere et al. 2013; Pammenter \& Berjak 2014; Walters 2015), including studies on ex situ conservation by storage (Pammenter et al. 1994; Drew et al. 2000; Li \& Pritchard 2009; Pasquini et al. 2012; Charloq et al. 2013; Walters et al. 2013; Bonjovani \& Barbedo 2014; Liu et al. 2014). Storage of recalcitrant seeds under desiccating conditions resulted in the initiation of subcellular damage, which may be repaired when seeds are set-out to germinate (Farrant et al. 1989; Tarquis \& Bradford 1992). However, when a critical proportion of cells are damaged, there will be total viability loss (Farrant et al. 1989). Storage is possible if the conditions preclude water loss, but such hydrated storage is strictly a short-term option because it will also promote germination metabolism with an accompanying increase in respiratory metabolism, favor a microbial contamination, and cause damage if water is not supplied in appropriate amounts (Farrant et al. 1989; Pammenter et al. 1994; Barbedo \& Marcos Filho 1998; Drew et al. 2000; Berjak \& Pammenter 2013). Therefore, high humidity also promotes the deterioration process (Barbedo \& Cicero 2000).

Some researchers have reported the early germination of A. angustifolia seeds during storage (Farrant et al. 1989; Garcia et al. 2014). Subcellular germination events, including an increase in the levels of protein synthesis and meristem cell metabolism, initiate shortly after the seeds of $A$. angustifolia are shed, and continue on during storage (Farrant et al. 1989).

Recalcitrant seed quality is influenced by drying after harvest, genetic potential, environmental conditions, harvest date, mechanical damage, and storage conditions

\footnotetext{
${ }^{1}$ Departamento de Fitotecnia, Universidade Federal de Santa Catarina, 88.034-001, Florianópolis, SC, Brazil

${ }^{2}$ Departamento de Agronomia, Universidade do Estado de Santa Catarina, 88.520-000, Lages, SC, Brazil

* Correspondig author: cileidesouza@udesc.br
} 
(Demir et al. 2008; Ligterink et al. 2012), and the determination of seed quality is a critical step for conservation, cultivation, breeding and research activities (Corbineau 2012). However, studies evaluating the quality of recalcitrant seeds, in general, do not consider the fact that germination metabolism may be active, and so assess seed quality in a manner similar to that done for more orthodox seeds.

Some authors have evaluated the decline in physiological quality of A. angustifolia seeds during storage (Fowler et al. 1998; Fontes et al. 2001; Piriz Carrillo et al. 2003; Caçola et al.2006; Amarante et al. 2007; Garcia et al. 2014). However, there have been no published reports on the characterization and standardization of germination metabolism after harvest, which begins immediately after physiological maturity and thus prior to quality evaluation. In view of the intraspecific variation typical of recalcitrant seeds (Li \& Pritchard 2009), a standardized assessment of physiological quality is necessary in order to determine a seeds developmental stage (Shibata et al. 2013). Thus, the aim of this work was to standardize the assessment of physiological quality of Araucaria angustifolia by identifying the initiation of the germination process during storage and to categorize seeds according to early developmental stage. More specifically the present study aimed to identify what stage of early development allows for the longest storage period, thus promoting seed conservation and providing a basis for further research on physiological quality of recalcitrant species.

\section{Material and methods}

\section{Plant material}

Mature cones of Araucaria angustifolia (Bert.) O. Ktze were collected in May 2012 from two natural populations: Lot 1 from the region of São José do Cerrito $\left(27^{\circ} 36^{\prime} \mathrm{S}, 50^{\circ} 39^{\prime} \mathrm{W}\right.$, average elevation of 918 meters); and Lot 2 from Painel $\left(27^{\circ} 55^{\prime} \mathrm{S}, 50^{\circ} 04^{\prime} \mathrm{W}\right.$, average elevation of 1171 meters), both in the state of Santa Catarina in southern Brazil. Both populations are located in areas of secondary forest (Mixed Rain Forest), with temperate $\mathrm{Cfb}$ climate according to Köppen classification, and relief from flat to slightly rolling. Cones were collected from $15 \pm 2$ matrices/population, for a total of $65 \pm 2$ cones/population. The collection of samples from two different populations was intended to better represent the species given the typical intraspecific diversity of recalcitrant seeds, and thus provide a stronger hypothesis test.

\section{Seed storage and determination of physiological quality}

Seed samples were homogenized and distributed among four replicates per lot, from which fractions were withdrawn and placed in sealed, semipermeable (porosity of 0.015 $\mu \mathrm{m})$, transparent plastic containers which permitted gaseous exchange yet limited water loss. The containers were then placed in two different storage conditions: the natural laboratory environment, and a cold chamber (temperature of $10 \pm 3^{\circ} \mathrm{C}$, and relative humidity of $45 \pm 5 \%$ ), where they were kept for a period of 270 days (each storage condition containing the four replicates per lot). Reference values for storage temperature and relative humidity for the natural laboratory environment are listed in Tab. 1.

Prior to assessment of quality, seeds were categorized according to early developmental stage. Determination of early developmental stage, and tests of moisture content, viability and vigor were performed at zero, 15, 30, 45, 90, $135,180,225$ and 270 days, for both lots and both storage conditions.

\section{Categorization of early developmental stages}

In order to standardize the assessment of viability and vigor, 35 seeds/replicate were assessed from both lots and both storage conditions. Seeds were separated into early developmental stages by visual characterization of seeds and/or embryos, which were manually extracted using a stylus and scalpel. This analysis allowed grouping seeds into four distinct categories (Fig. 1):

- Category I: seeds with mature (but not germinated) embryos, with whitish, pinkish or greenish cotyledons (Fig. 1A-B);

- Category II: seeds with embryos showing apparent elongation along the embryonic axis, indicating the beginning of germination (Fig. 1C-D);

Table 1. Reference temperature and relative humidity data for the city of Lages, SC, during storage of Araucaria angustifolia seed lots, according to Epagri/Ciram (2014).

\begin{tabular}{|c|c|c|c|c|c|c|}
\hline \multirow{2}{*}{ Storage Period (days) } & \multicolumn{3}{|c|}{ Temperature $\left({ }^{\circ} \mathrm{C}\right)$} & \multicolumn{3}{|c|}{ Relative humidity (\%) } \\
\hline & Mean & Maximum & Minimum & Mean & Maximum & Minimum \\
\hline $15-30$ & 13.3 & 24.8 & 0.9 & 83 & 98 & 35 \\
\hline 45 & 12.4 & 24.3 & 0.4 & 85 & 98 & 41 \\
\hline 90 & 11.7 & 24.0 & -0.5 & 85 & 98 & 43 \\
\hline 135 & 12.4 & 24.4 & 1.1 & 85 & 98 & 43 \\
\hline 180 & 13.4 & 26.0 & 1.6 & 83 & 98 & 42 \\
\hline 225 & 14.1 & 26.0 & 2.4 & 82 & 98 & 43 \\
\hline 270 & 15.5 & 27.0 & 4.3 & 81 & 98 & 42 \\
\hline
\end{tabular}


- Category III: seeds with embryos that started root protrusion, with seed coat rupture, and hypocotyl thickening; in general the cotyledons are greenish (Fig. 1E-F);

- Category IV: seeds with embryos in advanced stages of germination, with seedling shoots; cotyledons present, and the primary root being brownish (Fig. 1G-H).

In addition to visual analysis, embryo mass was determined using 10 seeds/replicate for each condition and storage period. Embryos were then extracted and categorized according to early developmental stage. Mean embryo mass was determined for each category, as was the percentage of seed mass represented by the embryo, regardless of the condition and storage period, in order to better characterize early developmental stages.

\section{Seed quality analysis during storage}

Moisture content was assessed through weight loss after oven drying at $105^{\circ} \mathrm{C} \pm 3^{\circ} \mathrm{C}$ for 24 hours, using three transversely cut seeds/replicate, (Brazil 2009). For analysis of seed viability, the Rules for Seed Analysis - RAS were used (Brazil 2009), which recommend the use of the tetrazolium test instead of the germination test, because of the extensive time-period before the formation of normal seedlings.

Therefore, viability was assessed using the tetrazolium test on 25 embryos/replicate, (according to methodology of Brazil 2009, with adaptations by Oliveira et al. 2014), and exudate $\mathrm{pH}$, according to methodology of Araldi et al. (2015). Both viability tests were based on the identification of viable structures associated with tissues appearance. An electrical conductivity test was performed with 10 embryos/ replicate immersed in $75 \mathrm{ml}$ of ultrapure water where they were kept for 12 hours at $25 \pm 1^{\circ} \mathrm{C}$, and the results reported in $\mu \mathrm{S} \mathrm{cm}^{-1} \mathrm{~g}^{-1}$ (Medeiros \& Abreu 2007).

Seeds from all categories were used for analysis of seed quality, however, only categories I and II will be presented in the results of viability analysis (tetrazolium and exudate $\mathrm{pH}$ exudate), since these categories better exhibited the differences between storage conditions and had a less substantial decline in viability.

\section{Experimental design and statistical analysis}

The experiment was conducted using a completely randomized design in split plot, with two storage conditions (natural environment and cold chamber) and nine storage periods $(0,15,30,45,90,135,180,225$ and 270 days). Percentage data were transformed into arc sin $\sqrt{ } \%$. Analysis of variance, Tukey test of means at 5\% probability, and regression analysis were performed using the statistical program SAS (2009). Since there were no significant differences between seed lots, viability analyses (tetrazolium and exudate $\mathrm{pH}$ ), moisture content and electrical conductivity were presented as a function of lot average.
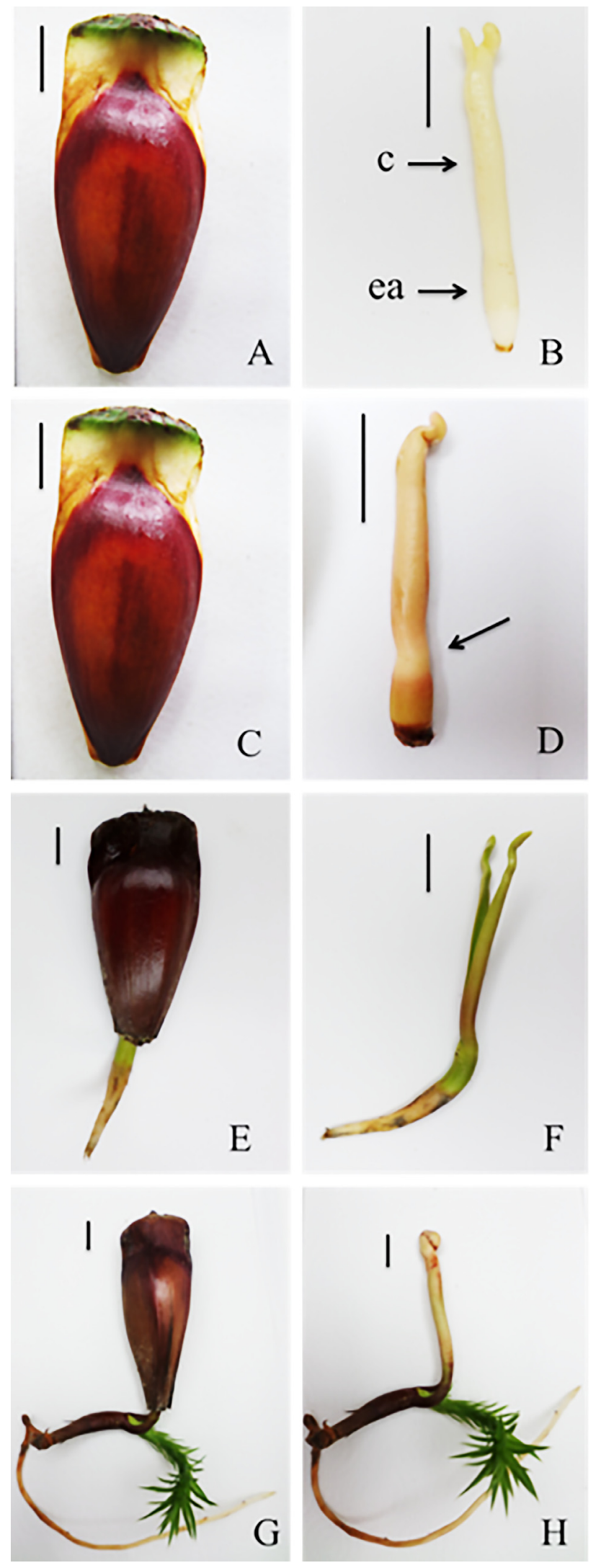

Figure 1. Appearance of Araucaria angustifolia seeds and embryos at early developmental stages I (A, B), II (C, D), III (E, F) and IV (G, H), observed during the storage period, showing cotyledons (c) and embryonic axes (ea). Bars indicate $1 \mathrm{~cm}$. 


\section{Results}

\section{Early development of seeds during storage}

The four early-developmental categories showed pronounced differences in embryo mass. Embryos belonging to category I averaged $0.12 \mathrm{~g}$ (Lot 1 ) and $0.14 \mathrm{~g}$ (Lot 2), representing $1.35 \%$ of the total seed mass (Tab. 2). There was an increase in embryo mass in category II $(0.25$ and $0.22 \mathrm{~g}$, for Lots 1 and 2, respectively) and category III ( 0.87 and $0.82 \mathrm{~g}$, for Lots 1 and 2, respectively). However, after root protrusion, embryo mass-gain was much higher, with it reaching close to $50 \%$ of total seed mass (Tab. 2).

Table 2. Embryo mass and relative percentage of total seed mass according to early developmental stage of Araucaria angustifolia.

\begin{tabular}{cccc}
\hline & $\begin{array}{c}\text { Early } \\
\text { developmental } \\
\text { category }\end{array}$ & $\begin{array}{c}\text { Mass/embryo } \\
(\mathrm{g})\end{array}$ & $\begin{array}{c}\text { \% relative to } \\
\text { the seed total } \\
\text { weight }\end{array}$ \\
\hline Lot 1 & I & 0.12 & 1.35 \\
& II & 0.25 & 3.06 \\
& III & 0.87 & 10.39 \\
CV (\%) & IV & 2.98 & 48.64 \\
\hline & I & 26 & 30 \\
\hline Lot 2 & II & 0.14 & 1.35 \\
& III & 0.22 & 2.31 \\
& IV & 3.25 & 11.11 \\
\hline CV (\%) & & 31 & 47.12 \\
\hline
\end{tabular}

Mass per embryo refers to the overall mean of embryos of each category, regardless of the condition and period of storage.
In freshly collected seeds, only embryos in category I were observed (Tab. 3). After 30 days of storage, embryos were found to be in categories II and III for both lots, and a decrease in the percentage of embryos in category I. After 45 days the percentage of embryos in category III increased substantially, with values close to $40 \%$ at 270 days for samples stored in the natural laboratory environment. The same trend was observed for the cold chamber samples, but with slightly lower percentages, approximately $33 \%$ of the embryos being in category III for both lots at 270 days, but embryos in category IV were not observed in the cold chamber.

The results show morphological changes typical of each early-developmental category, resulting in significant alterations in embryo mass, for all lots, conditions, and storage periods.

\section{Seed quality after storage}

Viability of embryos from freshly collected seeds, as determined by tetrazolium and exudate $\mathrm{pH}$ tests, was $96 \%$ and $95 \%$, respectively (Fig. 2A-B). Viability reduced sharply after 45 days of storage, and at the end of experimental period ( 270 days) viability was $4 \%$ (tetrazolium), and $5 \%$ (exsudate $\mathrm{pH})$ for embryos stored at natural laboratory environment, and 9\% (tetrazolium), and 13\% (exsudate $\mathrm{pH}$ ) for embryos stored in the cold chamber.

Viability should be related to moisture content, especially in recalcitrant seeds. Freshly collected seeds showed $49.5 \%$ moisture, and these values decreased during storage (Fig. 3). The sharpest reductions in moisture content occurred after 180 days of storage (moisture below $38 \%$ ), coinciding with the period in which embryo viability decreased to lower than $42 \%$ (tetrazolium) or $38 \%$ (exsudate $\mathrm{pH}$ ) for both storage conditions (Fig. 2A-B). At the end of the storage

Table 3. Percentage of Araucaria angustifolia seeds in early developmental categories I, II, III and IV, observed during storage in the natural laboratory environment and cold chamber.

\begin{tabular}{|c|c|c|c|c|c|c|c|c|c|c|c|c|c|c|c|c|c|c|c|}
\hline \multirow{3}{*}{ S.C. } & \multirow{3}{*}{ E.D. } & \multicolumn{9}{|c|}{ Lot 1} & \multicolumn{9}{|c|}{ Lot 2} \\
\hline & & \multicolumn{18}{|c|}{ Storage Period (days) } \\
\hline & & 0 & 15 & 30 & 45 & 90 & 135 & 180 & 225 & 270 & 0 & 15 & 30 & 45 & 90 & 135 & 180 & 225 & 270 \\
\hline \multirow{4}{*}{ Natural Environment } & I & 100 & 100 & 89 & 84 & 42 & 31 & 22 & 49 & 38 & 100 & 98 & 90 & 72 & 49 & 20 & 40 & 46 & 28 \\
\hline & II & - & - & 9 & 8 & 15 & 17 & 9 & 5 & 7 & - & 1 & 6 & 14 & 15 & 11 & 8 & 8 & 11 \\
\hline & III & - & - & 2 & 8 & 43 & 48 & 55 & 40 & 39 & - & 1 & 4 & 14 & 36 & 48 & 39 & 41 & 41 \\
\hline & IV & - & - & - & - & - & 4 & 14 & 6 & 16 & - & - & - & - & - & 21 & 13 & 5 & 20 \\
\hline CV (\%) & & 0 & 0 & 18 & 17 & 18 & 24 & 26 & 28 & 27 & 0 & 1 & 3 & 12 & 12 & 26 & 22 & 20 & 13 \\
\hline \multirow{4}{*}{ Cold Chamber } & I & 100 & 100 & 98 & 98 & 68 & 27 & 47 & 49 & 49 & 100 & 100 & 100 & 96 & 46 & 26 & 40 & 44 & 45 \\
\hline & II & - & - & 2 & 1 & 19 & 20 & 22 & 13 & 15 & - & - & - & 3 & 20 & 36 & 17 & 18 & 26 \\
\hline & III & - & - & - & 1 & 13 & 53 & 31 & 38 & 36 & - & - & - & 1 & 34 & 38 & 43 & 37 & 29 \\
\hline & IV & - & - & - & - & - & - & - & - & - & - & - & - & - & - & - & - & 1 & - \\
\hline CV (\%) & & 0 & 0 & 2 & 1 & 10 & 17 & 27 & 26 & 21 & 0 & 0 & 0 & 7 & 13 & 28 & 22 & 25 & 27 \\
\hline
\end{tabular}

Being: S.C. - storage condition; E.D. - early developmental category 


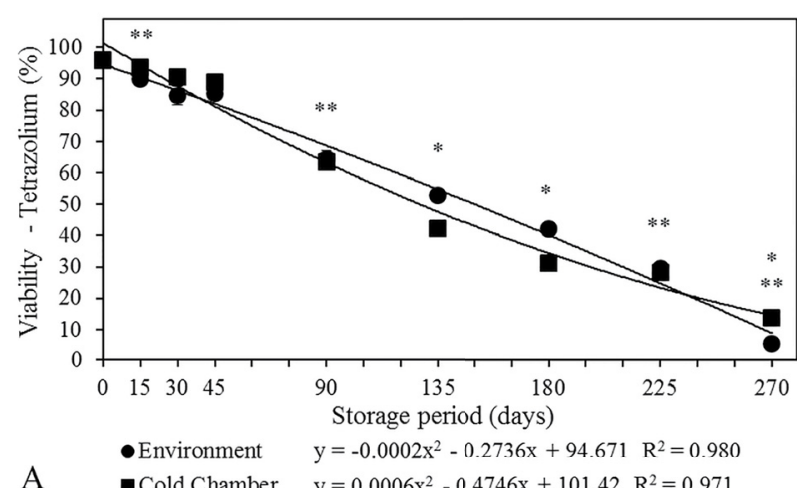

A Cold Chamber $\quad \mathrm{y}=0.0006 \mathrm{x}^{2}-0.4746 \mathrm{x}+101.42 \mathrm{R}^{2}=0.971$

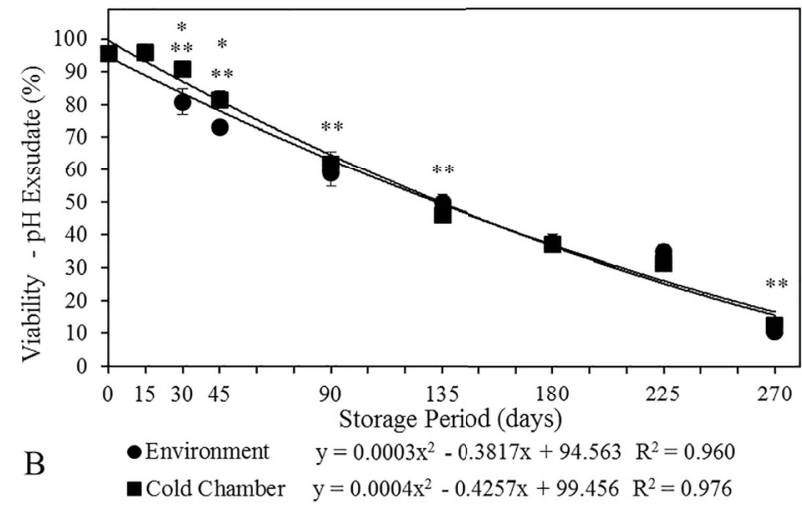

Figure 2. Viability of Araucaria angustifolia embryos assessed by tetrazolium (A) and pH exudate tests (B) of freshly collected seeds, and seeds in storage in the natural environment and dry chamber. Values represent the mean of seed lots from 4 replications $(n=25)$ for each treatment (from early developmental categories I and II), and vertical bars are the pooled standard errors of the mean (ANOVA). ${ }^{*}$ indicates the presence of significant differences between the mean of at least one storage condition treatment $(\mathrm{P} \leq 0.05)$ in each storage period. ${ }^{* *}$ indicates the presence of significant differences between the mean of the storage period treatment $(\mathrm{P} \leq 0.05)$ in relation to the previous period, for at least one storage condition.

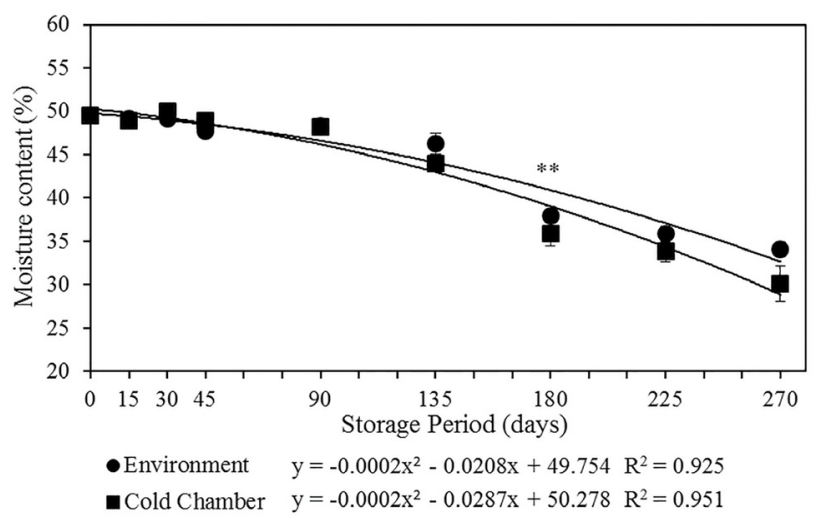

Figure 3. Moisture content of seeds of Araucaria angustifolia freshly collected and in storage in the natural environment and cold chamber. Values represent the mean of seed lots from 4 replicates $(n=3)$ for each treatment (from early developmental categories I, II, III and IV), and vertical bars are the pooled standard errors of the mean (ANOVA). ${ }^{*}$ indicates the presence of significant differences between the mean of at least one storage condition treatment $(\mathrm{P} \leq$ $0.05)$ in each storage period. ${ }^{* *}$ indicates the presence of significant differences between the mean of the storage period treatment $(\mathrm{P} \leq 0.05)$ in relation to the previous period, for at least one storage condition. period (270 days), moisture content of seeds reached $34 \%$ (natural environment), and 30\% (cold chamber).

Differences in embryo vigor, as assessed by electrical conductivity, between storage conditions were pronounced. In freshly collected samples, electrical conductivity was $64.3 \mu \mathrm{S} \mathrm{cm}^{-1} \mathrm{~g}^{-1}$, and the most significant differences between storage conditions occurred after 180 days (Fig. 4). At 270 days, electrical conductivity was $140.3 \mu \mathrm{S} \mathrm{cm}^{-1} \mathrm{~g}^{-1}$ (natural environment), and $332.4 \mu \mathrm{S} \mathrm{cm}^{-1} \mathrm{~g}^{-1}$ (cold chamber).

\section{Discussion}

Subcellular germination events of recalcitrant seeds initiate early after shedding (Drew et al. 2000; Obroucheva et al. 2012; Berjak \& Pammenter 2013). In fact, a decrease in the percentage of embryos in category I was observed after only 30 days of storage of A. angustifolia seeds, which suggests that germination metabolism certainly starts prior to this period. Recalcitrant seeds, including A. angustifolia, stored for 28 days at high relative humidity show protein digestion resulting in the formation of several vacuoles, plastids devoid of starch, and an increase in the number of mitochondria, all indicative of increased respiratory activity (Farrant et al. 1989). Therefore, A. angustifolia seeds remain metabolically active, and show changes associated with the process of germination while stored, a characteristic that forms the basis of recalcitrant behavior (Pammenter \& Berjak 2013).

In general, the percentage of embryos in category II was low in all treatments. This is because category II is a transition between the end of embryonic development (mature but not germinated embryos, typical category I), and the early formation of seedlings (physiologically germinated

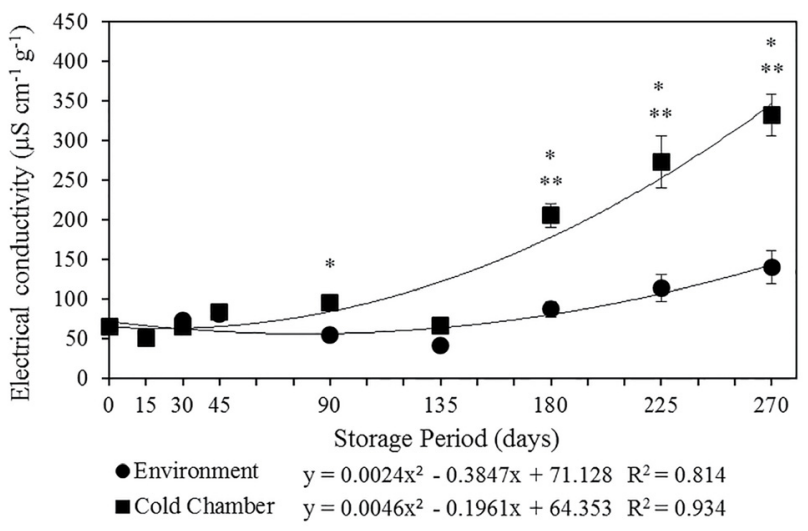

Figure 4. Electrical conductivity of Araucaria angustifolia embryos from freshly collected seeds, and from seeds in storage in the natural environment and dry chamber. Values represent the mean of seed lots from 4 replicates $(n=10)$ for each treatment (from early developmental categories I, II, III and IV), and vertical bars are the pooled standard errors of the mean (ANOVA). * indicates the presence of significant differences between the mean of at least one storage condition treatment $(\mathrm{P} \leq 0.05)$ in each storage period. ${ }^{* *}$ indicates the presence of significant differences between the mean of the storage period treatment $(\mathrm{P}$ $\leq 0.05$ ) in relation to the previous period, for at least one storage condition. 
embryos, typical category III). At the end of the experiment, most of the embryos that remained in categories I and II had deteriorated, being discolored and having visually softened tissue and/or damage from microorganisms. This is confirmed by results of the tests of physiological quality, which found a low percentage of viable seeds at 270 days of storage.

Viability decreased over the experimental period for both storage conditions, however, considering all earlydevelopmental categories (I to IV), viability values were, on average, $10 \%$ lower than considering only categories I and II for all storage periods (data not shown). This indicates that embryos in categories III and IV were more susceptible to deterioration. Furthermore, a more significant reduction in viability occurred with about $10 \%$ water loss, which favors deterioration. Once germination starts during storage, when there is a gradual increase in metabolic activity and water is necessary to complete the process, recalcitrant seeds including those of $A$. angustifolia, become increasingly sensitive to drought stress, and the damage caused by the lack of water triggers deterioration (Farrant et al. 1989; Fowler et al. 1998; Pammenter \& Berjak 2013; Walters 2015). Therefore, at the time when the water demand of seeds increased, it was also period of the lowest moisture levels, thus contributing to a sharp decline in viability. This makes it clear that the establishment of quality standards prior to physiological analysis is important for accurate assessment, and the segregation into early developmental categories should be considered. For seedling formation, seeds remaining in early developmental categories I and II can be kept in storage for future use, provided their physiological changes are periodically assessed during the storage period. Moreover, it is not possible to distinguish seeds in category I from those in category II without opening them and observing their embryos. Seeds with root protrusion (early developmental category III) should be used for propagation as quickly as possible. Following these measures would allow the most optimal storage and use of seeds of A. angustifolia.

The results presented herein suggest that heterogeneity in the degree of maturity of seeds is one of the most important aspects of determining the storability of A. angustifolia seed lots. Some authors have proposed that the period of viability of recalcitrant seeds during storage is dependent upon how developed the seeds are, considering that recalcitrant seeds differ from orthodox seeds only in the stage of maturity at which they were disconnected from mother plant (i.e., recalcitrant are immature dispersed seeds, Barbedo et al. 2013). Besides, there is natural variation in seed longevity, and the assignment of seeds to particular categories based on seed responses at full maturity is a difficult task because many recalcitrant seeds lack a clear punctuation between maturation and germination (Berjak \& Pammenter 2008; Walters 2015).

Decrease in embryo viability does not appear to have been strongly influenced by storage condition, possibly due to the use of sealed containers with small poros- ity that limited water loss. Furthermore, although there was a great temperature range in the natural laboratory environment, the average temperature in this condition $\left(15^{\circ} \mathrm{C}\right)$ was only slightly higher than that of the cold chamber $\left(10^{\circ} \mathrm{C}\right)$. More pronounced differences between storage conditions were observed in early developmental categories, wherein the samples in the natural laboratory environment reached categories II, III, and IV earlier than those in the cold chamber, since seeds of $A$. angustifolia germinated easily at temperatures ranging from $10^{\circ} \mathrm{C}$ to $30^{\circ} \mathrm{C}$ (Espíndola et al. 1994).

Electrical conductivity increased over the storage period and may be indicative of the onset of deterioration, given a lowered integrity of the cell membrane system of the seeds, which represents the initiation of the deterioration process (Matthews et al. 2012; Silva et al. 2014). The assessment of vigor using electrical conductivity showed a difference between storage conditions because the conductivity was higher in the cold chamber samples (lower vigor), compared to that of the samples in the natural laboratory environment (higher vigor), especially beginning at 135 days. Due to the sensitivity of the test, and since the natural laboratory environment condition had a higher average temperature and a higher temperature range than cold chamber, the laboratory environment samples were expected to have a higher rate of solute leaching. However, in the early developmental categories observed, the samples kept in the cold chamber had higher conductivity. This result can be explained by the correlation between physical characteristics and electrolyte leakage by seeds (Miceli \& Miceli 2012).

The process of the digestion of reserves during the development of seedlings of $A$. angustifolia originates in the embryo (Rosado et al. 1994), which leads to several morphological changes after they reach early-developmental categories III and IV, such as the thickening of the hypocotyl and primary root. At the seedling stage, the primary root is well-developed, cylindrical, woody, rusty in color, and with longitudinal ridges (Kuniyoshi 1983), and the hypocotyl is distinguished not only by the lack of lateral roots, but also by its extension, and its slightly greenish color (Dillenburg et al. 2010). Therefore, considering that seeds stored in the natural environment reached early developmental categories III and IV first, the morphological characteristics of developing seedlings provided a physical barrier preventing the leaching of solutes, and thus reducing electrical conductivity. Meanwhile, about $77 \%$ of seeds kept in the cold chamber were in categories I and II at 270 days (both lots), and thereby were more susceptible to solute leaching due to the disruption of the membrane system during the storage period. Thus, the electrical conductivity test was not sensitive enough to differentiate the physiological quality of seeds, unless their early developmental stages were previously established.

In summary, the results of this study demonstrate that the initiation of germination in stored seeds of $A$. angustifolia 
can be verified by visual analysis at about 30 days after collection. Seed storage in cold-chamber conditions delays germination, but does not prevent its occurrence. After reaching category III, embryos are more likely to deteriorate. Heterogeneity in the degree of maturation is one of the major causes of seed deterioration in A. angustifolia. Viability of $A$. angustifolia embryos can be kept around $12 \%$ after 270 days of storage in cold-chamber conditions. The lots of assessed seeds showed the same behavior with regard to physiological quality analysis, and were able to be separated into early developmental categories. Propagation purposes should prioritize the use of $A$. angustifolia seeds that have reached early developmental category III (with root protrusion), while those that remain in category I and II could be stored for 270 days in a cold chamber while maintaining at least $12 \%$ viability, provided there is periodic assessment for reduction in physiological quality.

\section{Acknowledgements}

The first author thanks FAPESC - Fundação de Amparo à Pesquisa e Inovação do Estado de Santa Catarina for providing a fellowship. The second author thanks $\mathrm{CNPq}$ - Conselho Nacional de Desenvolvimento Científico e Tecnológico for the research productivity fellowship.

\section{References}

Amarante CVT, Mota CS, Megguer CA, Ide GM. 2007. Conservação póscolheita de pinhões [sementes de Araucaria angustifolia (Bertoloni) Otto Kuntze] armazenados em diferentes temperaturas. Ciência Rural 37: 346-351.

Araldi CG, Coelho CMM. 2015. pH do exsudato na avaliação da viabilidade de sementes de Araucaria angustifolia. Floresta e Ambiente 22: 426-433.

Barbedo CJ, Bilia DAC. 1998. Evolution of research on recalcitrant seeds. Scientia Agricola 55: 121-125.

Barbedo CJ, Centeno DC, Ribeiro RCLF. 2013. Do recalcitrant seeds really exist? Hoehnea 40: 583-593.

Barbedo CJ, Cicero SM. 2000. Effects of inicial quality, low temperature and ABA on the storage of seeds of Inga uruguensis, a tropical species with recalcitrant seeds. Seed Science and Technology 28: 793-808.

Barbedo CJ, Marcos Filho J. 1998. Dessication tolerance in seeds. Acta Botanica Brasilica 12: 145-164.

Berjak P, Pammenter NW. 2008. From Avicennia to Zizania: seed recalcitrance in perspective. Annals of Botany 101: 213-228.

Berjak P, Pammenter NW. 2013. Implications of the lack of desiccation tolerance in recalcitrant seeds. Frontiers in Plant Science 4: 1-9.

Bonjovani MR, Barbedo CJ. 2014. Induction of tolerance to desiccation and to subzero temperatures in embryos of recalcitrant seeds of inga. Journal of Seed Science 36: 419-426.

Brasil. 2009. Ministério da Agricultura, Pecuária e Abastecimento. Regras para análise de sementes. Brasília, MAPA/ACS.

Caccere R, Teixeira SP, Centeno DC, Figueiredo-Ribeiro RCL, Braga MR. 2013. Metabolic and structural changes during early maturation of Inga vera seeds are consistent with the lack of a desiccation phase. Journal of Plant Physiology 170: 791-800.

Caçola AV, Amarante CVT, Fleig FD, Mota CS. 2006. Qualidade fisiológica de sementes de Araucaria angustifolia (Bertol.) Kuntze submetidas a diferentes condições de armazenamento e a escarificação. Ciência Florestal 16: 391-398.
Charloq, Lubis Z, Siregar TH, Elisa J, Sirait BA, Mathius NT. 2013. PEG 6000 ability test and fungicide efficacy in improving storability of shelled rubber (Hevea brasiliensis Muell.Arg) seed. Research Journal of Seed Science 6: 40-48.

Corbineau F. 2012. Markers of seed quality: from present to future. Seed Science Research 22: S61-S68.

Coutinho AL, Dillenburg LR. 2010. Comparison of seedling growth among three co-occurring varieties of Araucaria angustifolia (Bertol.) Kuntze under greenhouse conditions. Acta Botanica Brasilica 24: 567-570.

Demir I, Tekin A, Ökmen ZA, Okçu G, Kenanoglu BB. 2008. Seed quality, and fatty acid and sugar contents of pepper seeds (Capsicum annuum L.) in relation to seed development and drying temperatures. Turkish Journal of Agriculture and Forestry 32: 529-536.

Dillenburg LR, Rosa LMG, Mósena M. 2010. Hypocotyl of seedlings of the large-seeded species Araucaria angustifolia: an important underground sink of the seed reserves. Trees Structure and Function 24: 705-711.

Drew PJ, Pammenter NW, Berjak P. 2010. 'Sub-imbibed' storage is not an option for extending longevity of recalcitrant seeds of the tropical species, Trichilia dregeana Sond. Seed Science Research 10: 355-363.

Elbl P, Lira BS, Andrade SCS, et al. 2014. Comparative transcriptome analysis of early somatic embryo formation and seed development in Brazilian pine, Araucaria angustifolia (Bertol.) Kuntze. Plant Cell, Tissue and Organ Culture 120: 903-915.

Epagri/Ciram. 2014. Atlas climatológico do estado de Santa Catarina. Florianópolis, Epagri.

Espíndola LS, Noin M, Corbineau F, Côme D. 1994. Cellular and metabolic damage induced by desiccation in recalcitrant Araucaria angustifolia embryos. Seed Science Research 4: 193-201.

Farrant JM, Pammenter NW, Berjak P. 1989. Germination-associated events and the desiccation sensitivity of recalcitrant seeds - a study on three unrelated species. Planta 178: 189-198.

Fontes BPD, Davide LC, Davide AC. 2001. Fisiologia e citogenética de sementes envelhecidas de Araucaria angustifolia. Ciência e Agrotecnologia 25: 346-355.

Fowler JAP, Bianchetti A, Zanon A. 1998. Conservação de sementes de pinheiro-do-paraná sob diferentes condições de ambientes e embalagens. EMBRAPA/CNPF, Comunicado Técnico 34: 1-4.

Garcia C, Coelho CMM, Maraschin M, Oliveira LM. 2014. Conservação da viabilidade e vigor de sementes de Araucaria angustifolia (Bert.) O. Kuntze durante o armazenamento. Ciência Florestal 24: 857-866.

IUCN. 2013. Red List of Threatened Species. International Union for the Conservation of Nature, Cambridge, United Kingdom.

Kuniyoshi YS. 1983. Morfologia da semente e da germinação de 25 espécies arbóreas de uma floresta com araucária. Dissertation, Federal University of Paraná, Curitiba, Brazil.

Li DZ, Pritchard HW. 2009. The science and economics of ex situ plant conservation. Trends in Plant Science 14: 614-621.

Ligterink W, Joosen RVL, Hilhorst HWM. 2012. Unravelling the complex trait of seed quality: using natural variation through a combination of physiology, genetics and -omics technologies. Seed Science Research 22: S45-S52.

Liu Q, Lan QY, Wen B, Tan YH, Wang XF. 2014. Germination of recalcitrant Baccaurea ramiflora seeds. Science Asia 40: 101-105.

Matthews S, Noli E, Demir I, KhajehHosseini M, Wagner MH. 2012. Evaluation of seed quality: from physiology to international standardization. Seed Science Research 22: S69-S73.

Medeiros ACS, Abreu DCA. 2007. Flash-drying for embryos desiccation. Pesquisa Florestal Brasileira 54: 119-125.

Miceli A, Miceli C. 2012. Effect of thermal treatments on vitality and physical characteristics of bean, chickpea and lentil. Journal of Stored Products Research 51: 86-91.

Obroucheva NV, Lityagina SV, Novikova GV, Sin'kevich IA. 2012. Vacuolar status and water relations in embryonic axes of recalcitrant Aesculus hippocastanum seeds during stratification and early germination. AoB Plants 2012: 1-14.

Oliveira LM, Gomes JP, Souza GK, Nicoletti MF, Liz TO, Pikart TG. 2014. Metodologia alternativa para o teste de tetrazólio em sementes de Araucaria angustifolia (Bertol.) Kuntze. Floresta e Ambiente 21: 468-474. 
Pammenter NW, Berjak P. 2013. Development of the understanding of seed recalcitrant and implications for ex situ conservation. BiotecnologíaVegetal 13: 131-144.

Pammenter NW, Berjak P. 2014. Physiology of desiccation-sensitive (recalcitrant) seeds and the implications for cryopreservation. International Journal of Plant Sciences 175: 21-28.

Pammenter NW, Berjak P, Farrant JM, Smith MT, Ross G. 1994. Why do stored hydrated recalcitrant seeds die? Seed Science Research 4: 187-191.

Pasquini S, Mizzau M, Petrussa E, et al. 2012. Seed storage in polyethylene bags of a recalcitrant species (Quercus ilex): analysis of some bio-energetic and oxidative parameters. Acta Physiolgia Plantarum 34: 1963-1974.

Piriz Carrillo V, Chaves A, Fassola H, Mugridge A. 2003. Refrigerated storage of seeds of Araucaria angustifolia (Bert.) O. Kuntze over a period of 24 months. Seed Science and Technology 31: 411-421.

Reis MS, Ladio A, Peroni N. 2014. Landscapes with Araucaria in South America: Evidence for a cultural dimension. Ecology and Society 19: 43-56.

Rosado RM, Ferreira AG, Mariath JEA, Cocucci AE. 1994. Amido no megagametófito de Araucaria angustifolia (Bert.) O. Ktze: degradação durante a germinação e desenvolvimento do esporófito. Acta Botanica Brasilica 8: 35-43.

SAS. 2009. SAS Institute Inc ${ }^{\circledR}$ 2009. Cary, NC, USA, Lic. UDESC: SAS Institute Inc.
Shibata M, Coelho CMM, Steiner N. 2013. Physiological quality of Araucaria angustifolia seeds at different stages of development. Seed Science and Technolology 41: 214-224.

Silva VN, Zambiasi CA, Tillmann MAA, Menezes NL, Villela FA. 2014. Condução do teste de condutividade elétrica utilizando partes de sementes de feijão. Revista de Ciências Agrárias 37: 206-213.

Silveira V, Santa-Catarina C, Balbuena TS, et al. 2008. Endogenous abscisic acid and protein contents during seed development of Araucaria angustifolia. Biologia Plantarum 52: 101-104.

Song SQ, Berjak P, Pammenter N, Ntuli TM, Fu JR. 2003. Seed recalcitrance: a current assessment. Acta Botanica Sinica 45: 638-643.

Stefenon VM, Steiner N, Guerra MP, Nodari RO. 2009. Integrating approaches towards the conservation of forest genetic resources: a case study of Araucaria angustifolia. Biodiversity and Conservation 18: 2433-2448.

Tarquis A M, Bradford KJ. 1992. Prehydration and priming treatments that advance germination also increase the rate of deterioration of lettuce seeds. Journal of Experimental Botany 43: 307-317.

Veloso HP, Rangel Filho ALR, Lima JCA. 1991. Classificação da vegetação brasileira, adaptada a um sistema universal. Rio de Janeiro, IBGE.

Walters C. 2015. Orthodoxy, recalcitrance and in-between: describing variationin seed storage characteristics using threshold responses to water loss. Planta 242: 397-406.

Walters C, Berjak P, Pammenter N, Kennedy K, Raven P. 2013. Preservation of recalcitrant seeds. Science 339: 915-916. 